\title{
Patient with Refractory Epilepsy Associated with Oligondendroglioma
}

\author{
Mauricio Vaillant Amarante*, Ozinelia Pedroni Batista, Camilia Lampier Lutzke, \\ Shirley Kempin Quiqui
}

Department of Family and Community Health Strategy, Municipal Government of Domingos Martins, Domingos Martins, Espírito Santo, Brazil

\author{
Email address: \\ mauriciovaillant@hotmail.com (M. V. Amarante) \\ ${ }^{*}$ Corresponding author
}

\section{To cite this article:}

Mauricio Vaillant Amarante, Ozinelia Pedroni Batista, Camilia Lampier Lutzke, Shirley Kempin Quiqui. Patient with Refractory Epilepsy Associated with Oligondendroglioma. Clinical Neurology and Neuroscience. Vol. 3, No. 2, 2019, pp. 43-45.

doi: $10.11648 /$ j.cnn.20190302.13

Received: April 23, 2019; Accepted: June 5, 2019; Published: June 20, 2019

\begin{abstract}
Oligodendroglioma is a rare form of primary brain tumor, accounting for about 2-5\% of intracranial tumors, being more common in adult males but rare in children, accounting for about $1-2 \%$ of all primary brain tumors in children. It originates from oligodendrocytes or glial precursor cells and exhibits infiltrative and slow growth. They can be classified in two grades (Grade II and Grade III), where Grade II are low grade tumors and have tumor cells that grow slowly and invade nearby normal tissue, and Grade III are malignant and have rapidly growing tumors. It has low growth and 50-80\% of cases first symptom is seizures. A seizure is a symptom that requires a rapid solution usually requiring empirical treatment at the initial time to cease seizures and promote some well-being for the patient's routine. Seizures can cause a lot of damage to the patient's life, especially if the patient is a child who does not know what to do and what to do. Depending on the intensity and frequency of seizure episodes, the patient may experience fractures with falls, may suffer discrimination and prejudice at school. The causes behind refractory epilepsy are diverse, so whenever a patient is found to be refractory to drug treatment, the origin of seizures should be investigated early, it is not enough to stop at empirical treatment.
\end{abstract}

Keywords: Olingodendroglioma, Refractory Epilepsy, Primary Brain Tumors

\section{Introduction}

Olingodendroglioma is a form of primary brain tumor, more common in adult males, in recent studies show that oligodendrogliomas represent about $2-5 \%$ of all intracranial tumors, being rare in children, $1-2 \%$ of the cases.[1] Characterized by growth infiltrative and slow, originate in the oligodendrocytes, nerve cells lining the neurons providing electrical insulation, their histogenesis is still uncertain, but seems to be linked to deletion of the arm $\mathrm{p}$ of chromosome 1 in $83 \%$ cases, deletion of the $\mathrm{q}$ arm of the chromosome 19 in $72 \%$, and both deletions in $69 \%$ cases. There was no significant difference in the absence of $1 \mathrm{p} / 19 \mathrm{q}$ in low- and high-grade oligodendrogliomas, presents an indolent course and a good prognosis when compared to other glial neoplasias. [2-3]

Oligodendrogliomas are grouped in two grades: 1. Grade
II - oligodendrogliomas are low-grade tumors. This means the tumor cells slowly grow and invade nearby normal tissue. In many cases, they have not been diagnosed. 2. Grade III oligodendrogliomas are malignant (cancerous). This means they are fast-growing tumors. They are called anaplastic oligodendriogliomas. [4]

Because of their diffusely infiltrating nature, oligodendrogliomas cannot be completely resected and are not curable by surgical excision, in the most of cases, but compared to the more common astrocytomas, they are slowly growing with prolonged survival, and had a good prognosis, your indolent nature and the potential morbidity associated with neurosurgery, chemotherapy and radiotherapy contribute to the neuro-oncologists to decide initially pursue a course of watchful waiting and treat empirically patients symptomatically with anticonvulsants for seizures and steroids for brain swelling. 


\section{[5-7]}

Oligodendrogliomas, like all other infiltrating gliomas, have a very high rate of recurrence and gradually increase in grade over time. Recurrent tumors are generally treated with more aggressive chemotherapy and radiation therapy. Recently, stereotactic surgery has proven successful in treating small tumors that have been diagnosed early.

\section{Case Report}

E.S., female, 33 years old, ballet teacher, at 11 years old developed epilepsy, seizures occurred at night, during sleep she screamed, urinated and presented chorea, 3 times per week, at 13 years old began have wakefulness aura-preceding seizures: dyspnea, tachycardia and deja vu; without sphincter loss, but losing consciousness and absence crisis, began use fenoprofen due post-ictal headache and phenytoin, also started depression, with several suicide attempts and mutilation, due prejudice in school. Between 16 and 18 years old, followed non-periodically with a neurologist, using carbamazepine, phenytoin, phenobarbital and diazepam, without improvement, became pregnant and only taken phenobarbital, seizures were less frequent, with the same amount of absence crisis, that was up to the 30th week due frequent seizures, when worsened in intensity and frequency with complete sphincter loss and weight loss, taking medications prior to pregnancy, sought another neurologist, done MRI of the brain: with nodular image in the lower portion, located in the right temporal lobe, next to the inferior temporal gyrus and exerting a compressive effect on the head of hippocampus, diagnosed as oligodendroglioma, referred to the neurosurgery, made a video-EEG, confirming tumor, proceed right temporal lobectomy, forwards to the oncology service, without chemo or radiotherapy, between 2004 and 2012, there was considerable seizures decrease, 1 per month, and also absence crisis decrease, with episodes of immediate memory loss, in regular use of phenytoin, during follow-up, seizures returned in the same intensity and frequency before surgery, was attended by another neurologist, prescribed valproic acid, phenytoin, obtained the right to consult with the neurologist who operated on after a court decision, kept only carbamazepine, new video-EEG: migration of the convulsive focus to the left side of the brain, the vagal pacemaker was implanted in June 2014, with significant improvement, reports also episodes of aura 2-3 times per weeks without seizures, without improvement of absence crisis or immediate memory loss.

\section{Discussion}

Oligodendroglioma is a rare form of brain tumor, represents about $1-2 \%$ of all primary brain tumors in children, originate on oligodendrocytes or in precursor glial cells, had low growth and $50-80 \%$ of cases first symptom is seizures, other symptoms are headaches, problems with thinking and memory, weakness, numbness, or problems with balance and movement.
The tumors, because have a indolent growth and the benign character, can be follow with periodic medical checkup in patients that have response with medication for the symptoms, like anticonvulsants for the seizures and steroids for the brain swelling, without neurosurgery.

In our case, was tried a several medication treatment, using four medications at the same time for years, without improvement, when a new neurologist decide to proceed with a MRI, trying in this way to discover a primary cause for the symptoms, diagnoses an Oligodendroglioma and proceed finally to a neurosurgery.

Our patient be almost asymptomatic for 8 years, when the seizures returned in the same in the same intensity and frequency before surgery, one more time, because the bureaucracy of Brazilian healthy system, she was attended by another neurologist instead of the same one who operated it, who tried again a drug treatment, without improvement, only then being referred to the neurologist who operated it, which attempted again an empirical drug treatment, without improvement, only then was referred to the neurologist who operated it, who again sought the primary cause for the symptoms, in addition to maintaining the empirical treatment.

\section{Conclusion}

The causes behind refractory epilepsy are diverse, so whenever faced with a patient refractory to drug treatment, should be investigated early, in order to find the primary cause for the symptoms, the idiopathic form should be a diagnosis of exclusion, but the fact that it does not have a definite primary cause should not delay the beginning of the empirical treatment, aiming above all for a better quality of life to the patient, which should be the main goal to be achieved in medical care.

We must always remember that when a person is sick, it does not only affect the sick person, it affects the entire family and can affect a community, when there is no educated population, creating a prejudiced environment, not only physically impairing the patient, but can also cause serious psychiatric damage, and may have tragic outcomes such as suicide, so we must be aware not only of the physical demands but also of how the process of becoming ill is affecting our patient mentally.

\section{Conflicts of Interest}

All the authors do not have any possible conflicts of interest.

\section{References}

[1] MORENO-JIMENEZ, Sergio et al. Oligodendrogliomas en el Instituto Nacional de Neurología y Neurocirugía: comportamiento biológico en una población definida. Arch. Neurocien. (Mex., D.F.) [online]. 2005, vol.10, n.3, pp.140145. $<$ http://www.scielo.org.mx/scielo.php?script=sci_arttext\& pid $=$ S0187-47052005000300004\&lng=es\&nrm=iso $>$. ISSN 0187-4705. 
[2] Barbashina V, Salazar P, Holland EC, Rosenblum MK, Ladanyi M (1 February 2005). "Allelic losses at 1p36 and $19 q 13$ in gliomas: correlation with histologic classification, definition of a $150-\mathrm{kb}$ minimal deleted region on $1 \mathrm{p} 36$, and evaluation of CAMTA1 as a candidate tumor suppressor gene". Clin. Cancer Res. 11 (3): 1119-28. PMID 15709179.

[3] Ducray F, Idbaih A, de Reyniès A, et al. (2008). "Anaplastic oligodendrogliomas with $1 \mathrm{p} 19 \mathrm{q}$ codeletion have a proneural gene expression profile". Mol. Cancer. 7: 41. doi: 10.1186/1476-4598-7-41. PMC 2415112. PMID 18492260.

[4] Louis D, Ohgaki H, Wiestler O, et al. (2007). "The 2007 WHO Classification of Tumours of the Central Nervous System". Acta Neuropathologica. 114 (2): 97-109. doi: 10.1007/s00401-007-0243-4. PMC 1929165. PMID 17618441 .

[5] Hamlat A, Saikali S, Chaperon J, et al. (November 2005). "Oligodendroglioma: clinical study and survival analysis correlated with chromosomal anomalies". Neurosurg Focus. 19 (5): E15. doi:10.3171/foc.2005.19.5.16. PMID 16398465.

[6] Lassman, A. B. (20 May 2009). "Retrospective analysis of outcomes among more than 1,000 patients with newly diagnosed anaplastic oligodendroglial tumors". Journal of Clinical Oncology. 27 (15S): 2014. doi: 10.1200/jco.2009.27.15s.2014 (inactive 2019-02-12). ISSN 0732-183X.

[7] Sunyach MP, Jouvet A, Perol D, et al. (December 2007). "Role of exclusive chemotherapy as first line treatment in oligodendroglioma". J. Neurooncol. 85 (3): 319-28. doi: 10.1007/s11060-007-9422-3. PMID 17568995.

[8] Ohgaki H, Kleihues P (June 2005). "Population-based studies on incidence, survival rates, and genetic alterations in astrocytic and oligodendroglial gliomas". J Neuropathol Exp Neurol. 64 (6): 479-489. doi:10.1093/jnen/64.6.479. PMID 15977639.

[9] Feigenberg SJ, Amdur RJ, Morris CG, Mendenhall WM, Marcus RB, Friedman WA (2003). "Oligodendroglioma: does deferring treatment compromise outcome?". Am. J. Clin. Oncol. $26 \quad$ (3): 60-66. doi: 10.1097/01.COC.0000072507.25834.D6. PMID 12796617.

[10] Brainer-Lima PT, Mertens Brainer-Lima A, Rocha AzevedoFilho H. Ganglioglioma: comparison with other low-grade brain tumors. Arq. Neuro-Psiquiatr. 64 (3a): 613-618. doi: 10.1590/S0004-282X2006000400018.

[11] Huang CI, Chiou WH, Ho DM (December 1987). "Oligodendroglioma occurring after radiation therapy for pituitary adenoma". Journal of Neurology, Neurosurgery \& Psychiatry. 50 (12): 1619-24. doi: 10.1136/jnnp.50.12.1619. PMC 1032603. PMID 3325615.
[12] Laigle-Donadey F, Benouaich-Amiel A, Hoang-Xuan K, Sanson M (2005). "[Molecular biology of oligodendroglial tumors]". Neuro-Chirurgie (in French). 51 (3-4 Pt 2): 260-8. doi: 10.1016/s0028-3770 (05)83487-3. PMID 16292170.

[13] Walker C, Haylock B, Husband D, et al. (2006). "Clinical use of genotype to predict chemosensitivity in oligodendroglial tumors". Neurology. 66 (11): 1661-7. doi: 10.1212/01.wnl.0000218270.12495.9a. PMID 16769937.

[14] Sérgio Reis Filho, J., et al. Oligodendrogliomas: estudo anatomopatológico e clínico de 15 casos. Arq. NeuroPsiquiatr. 57 (2A): 249-54. doi: 10.1590/S0004282X1999000200013 . PMID:10412525.

[15] Agapejev S., et al. Oligodendroglioma cístico e positividade das reações para cisticercose relato de caso. Arq. Neuro$\begin{array}{llll}\text { Psiquiatr. } \quad 50 & \text { (2): } 234-38 . & \text { doi: } 10.1590 / \mathrm{S} 0004-\end{array}$ 282X1992000200020.

[16] Marques-Assis L, Guenni-Bejar D, Faria Lins Evaldo J. A epilepsia nos tumores cerebrais. Arq Neuro-Psiquiatr. 27 (1): 31-40. doi: 10.1590/S0004-282X1969000100002.

[17] Souza Barboza E, et al. Meningeoma pós-radioterapia. Arq. Neuro-Psiquiatr. 64 (3b): 794-797. doi: 10.1590/S0004282X2006000500017.

[18] Reyes-Botero, Germán, Naranjo, Luis Fermín, Tobón, Vladimir, Franco, César, Álvarez, Juan Felipe, \& Barrientos, Hernán. (2017). Uso de anticonvulsivantes en epilepsia secundaria a gliomas en adultos: serie de casos. Acta $\begin{array}{llll}\text { Neurológica Colombiana, } 33 & \text { (3), 148-153. }\end{array}$ https://dx.doi.org/10.22379/24224022149.

[19] Ramos, Tiago D. P., \& Amorim, Lidia M. F.. (2015). Molecular biology techniques for loss of heterozygosity detection: the glioma example. Jornal Brasileiro de Patologia e $\begin{array}{llll}\text { Medicina } & \text { Laboratorial, } & 51 & \text { (3), }\end{array}$ https://dx.doi.org/10.5935/1676-2444.20150033.

[20] Abrigo JM, Fountain DM, Provenzale JM, Law EK, Kwong JSW, Hart MG, Tam WWS. Magnetic resonance perfusion for differentiating low-grade from high-grade gliomas at first presentation. Cochrane Database of Systematic Reviews 2018, Issue 1. Art. No.: CD011551. DOI: 10.1002/14651858.CD011551.pub2.

[21] Sarmiento JM, Venteicher AS, Patil CG. Early versus delayed postoperative radiotherapy for treatment of low-grade gliomas. Cochrane Database of Systematic Reviews 2015, Issue 6. Art. No.: CD009229. DOI: 10.1002/14651858.CD009229.pub2. 